University for Business and Technology in Kosovo

UBT Knowledge Center

Nov 2nd, 9:00 AM - Nov 3rd, 5:00 PM

\title{
The New Law of the Territory Planning, an Innovation for Local Government Units, an Ongoing Process
}

Hermina Albunesa

Ing. Fatlum Nurja, albunesa@yahoo.com

Follow this and additional works at: https://knowledgecenter.ubt-uni.net/conference

Part of the Architecture Commons

\section{Recommended Citation}

Albunesa, Hermina, "The New Law of the Territory Planning, an Innovation for Local Government Units, an Ongoing Process" (2012). UBT International Conference. 23.

https://knowledgecenter.ubt-uni.net/conference/2012/all-events/23

This Event is brought to you for free and open access by the Publication and Journals at UBT Knowledge Center. It has been accepted for inclusion in UBT International Conference by an authorized administrator of UBT Knowledge Center. For more information, please contact knowledge.center@ubt-uni.net. 


\title{
THE NEW LAW OF THE TERRITORY PLANNING, AN INNOVATION FOR LOCAL GOVERNMENT UNITS, AN ONGOING PROCESS ....!
}

\author{
M.A Hermina ALBUNESA, Ph.d Candidate ${ }^{1}$ \\ MPA Ing. Fatlum NURJA ${ }^{2}$ \\ Ialbunesa@yahoo.com \\ ²nurja@plgp.al
}

\begin{abstract}
Urban planning is a function of local government units set out in the article 10 of Law No. 8652, dated 31.7.2000 "On the organization and functioning of local government units"

This paper will be based on legal analysis that local governments units are facing today, by highlighting the differences between the old and the new legislation for the territory, concerning the new instruments of territorial planning.

It is passed from the traditional planning law with rules on architecture of the buildings, which had to do with the protection of legitimate interests related to private property, in a law which does not consist only on rules, but it speaks for planning and development.

The effective implementation of this law is closely connected to the legislation for the development of physical and social infrastructure in local level, local taxes and fees and management of immovable property of the $L G U$.

An important concept of the law of the territory, in difference with urban law that quoted the protection of legitimate interests related to private property, is that the new law does not distinguish between private land and state land.

This law establishes rules for rational use of land and determines how these rules must be applied, rules that intend to balance public interest with private interests and turn the local authority by a follower of the private initiative in a developing leaders.

$L G U$ are responsible and can provide their local power autonomy in function of planning and development of the territory, if they compose their overall planning instruments.
\end{abstract}

Key words: urban planification, development, local planning instrument, territory, 